\title{
Comparing Performance of Various Crops in Rajasthan state based on Market Price, Economic Prices and Natural Resource Valuation
}

\author{
M.K. Jangid ${ }^{1}$, Latika Sharma ${ }^{1}$, S.S. Burark ${ }^{1}$, H.K. Jain ${ }^{2}$, G.L. Meena ${ }^{1}$ and S.L. Mundra ${ }^{3}$
}

${ }^{1}$ Department of Agricultural Economics and Management, Rajasthan College of Agriculture, Maharana Pratap University of Agriculture and Technology, Udaipur, Rajasthan, India

${ }^{2}$ Department of Agricultural Statistics and Computer Application, Rajasthan College of Agriculture, Maharana Pratap University of Agriculture and Technology, Udaipur, Rajasthan, India

${ }^{3}$ Department of Agronomy, Rajasthan College of Agriculture, Maharana Pratap University of Agriculture and Technology, Udaipur, Rajasthan, India

Corresponding author: jangidmkindia2007@gmail.com

\begin{abstract}
The study has assessed the performance of different crops and cropping pattern in the state of Rajasthan using alternative price scenarios like market prices; economic prices (net out effect of subsidy) and natural resource valuation (NRV) considering environmental benefits like biological nitrogen fixation and greenhouse gas costs. The study has used unit-level cost of cultivation data for the triennium ending 2013-14 which were collected from Cost of Cultivation Scheme, MPUAT, Udaipur (Raj.) for the present study. It has analyzed crop-wise use of fertilizers, groundwater, surface water and subsidies. The secondary data of cropping pattern was also used from 1991-95 to 2011-14 from various published sources of Government of Rajasthan. The study that even after netting out the input subsidies and effect on environment and natural resources, the cotton-vegetables cropping pattern was found more stable and efficient because of the higher net return of ₹ 102463 per hectare with the next best alternate cropping patterns like clusterbean-chillies ( $₹$ 86934/ha), cotton-wheat ( $₹$ 69712/ha), clusterbean-wheat ( $₹$ 64987/ ha) etc. under the set of marketing infrastructure, minimum support prices, agricultural technological know-how, climatic conditions in the various zones, available irrigation facilities. The study has pointed out that the grower farmers may not move towards the diversification until incentivized by economically attractive alternate cropping patterns.
\end{abstract}

Keywords: Crop diversification, cropping intensity, market price, economic price and natural resource valuation

Agricultural land use study has acquired special significance in the realm of the present day problem oriented studies of the growth and resource utilization. At present, per capita availability of cultivable land in India has declined from 0.48 hectare in 1951 to 0.12 hectare in 2014-15 which would be declined to 0.08 hectare in 2050 . Agricultural land of India is 182 million hectares and 67 million hectares constitute forest land. Rajasthan with its huge geographical area of 342.7 lakh hectares is the largest state of India. The state is predominantly an agriculture state with 75 per cent population living in rural areas. Agriculture and allied activities contributed 26.54 per cent of Net State Value Added at constant price 2011-12 while its share in Gross State Value Added is 25.92 per cent during 2016-17 (Economic Review, 201718). Agriculture is the single largest sector of the state economy employing 70 per cent labour force directly and indirectly. Rajasthan state has witnessed an extreme level of groundwater over-exploitation. Total annual groundwater draft in the state is 15.71 billion cubic meter which is higher than the sustainable limit of 11.26 billion cubic meter. 
Central ground water board has categorized 164 blocks out of 248 blocks as over-exploited which is 68.33 per cent of total assessment unit. Only 17.74 per cent ( 44 blocks) of the total blocks were categorized in safe category (CGWB, 2017). The Net area irrigated by all sources during 2015-16 was 79.38 lakh hectares as against 78.82 lakh hectare in 2014-15 showing an increase of 0.71 percent. The net irrigated area during 2015-16 constituted 44.04 percent of net area sown in the state. In the Rajasthan state (Agriculture Statistics of Rajasthan, 2015-16), cropping pattern is inefficient in terms of resource use and unsustainable from natural resource use point of view.

This leads to serious misallocation of resources, efficiency loss, indiscriminate use of land and water resources, and it adversely affects long term production prospects. Crop selection at regional level is one such challenge which can be addressed using optimum crop planning. As such regional crop planning is very crucial that helps to formulate region specific crop planning which would optimize the level of each activity of different crops, level of input use and output produced under different resource endowments and price scenarios. It involves area allocation for each of these crops, the sequencing of crops, and the irrigation plans. Best suitable crops and other enterprises should be selected so as to achieve some set of goals particular to the region. Typically, these goals involve the maximization of net income, the minimization of cost, the maximization of total area cultivated, and/ or the minimization of irrigation water. Keeping in view the above considerations, a research study entitled "Comparing Performance of Various Crops in Rajasthan state based on Market Price, Economic Prices and Natural Resource Valuation" was conducted.

\section{METHODOLOGY}

The study was conducted based on plot level secondary data. The data were collected from the 600 representative households of 60 cluster villages during each year of the block period (2011-12 to 2013-14) from the Cost of Cultivation Scheme, Rajasthan. The secondary data were collected from various published records and reports of Government of Rajasthan and Government of India from the year 1990-91 to 2013-14.

\section{Changes in Cropping Pattern}

To capture the extent of diversification in the state, Simpson's Index (SI) of Diversification has been employed to measure degree of crop diversification and was explained as follows:

$$
\mathrm{SI}=1-\Sigma(\mathrm{pi} / \Sigma \mathrm{pi})^{2}
$$

Where,

$p i$ is the area proportion of the $i^{\text {th }}$ crop in total cropped area and

$i=1,2,3, \ldots . n$. is the number of crops

The value of index increases with the increase in diversification and assumes 0 (zero) value in case of perfect concentration. The crop diversification study was based on time-series data for the time period 1990-91 to 2013-14.

The performance of different crops were assessed by comparing net returns under alternative scenario. These are: (i) Market Price (ii) Economic Price and (iii) Natural Resource Valuation Technique (Raju et al. 2015).

\section{Net Returns at Market Prices $\left(\mathrm{NR}_{\mathrm{MP}}\right)$}

Net returns at market price was defined as the gross return (value of main product and by product) less variable costs (Cost $\mathrm{A} 1+$ imputed value of family labour) at market price actually paid and received by the farmer or imputed in some cases.

$$
\mathrm{NR}_{\mathrm{MP}}=\mathrm{GR}-\mathrm{VC}
$$

Where,

$$
\begin{aligned}
& \mathrm{NR}_{\mathrm{MP}}-\text { Net return at market price, } \\
& \text { GR- Gross Returns and } \\
& \text { VC- Variable Cost. }
\end{aligned}
$$

Cost $A_{1}$ as defined in Manual on Cost of Cultivation Scheme, DES, New Delhi includes all actual expenses in cash and kind in production by the farmer. Some of the components of cost $\mathrm{A}_{1}$ directly retrieved from the unit level data set of cost of cultivation scheme, while few are estimated for example: depreciation of implements and farm building, interest on working capital has been computed by using the method elaborated in the manual on CCS. 
The imputed value of family labour has been calculated as:

Imputed Value of Family Labour $=$ Working Hours of Family Labour $\times$ Labour Wage Rate per Hour

\section{Net Returns at Economic Price $\left(\mathrm{NR}_{\mathrm{EP}}\right)$}

Net return at economic price was defined as the difference between net return or income at market price and subsidies on inputs like fertilizers and irrigation used in crop production.

$$
\text { i.e. } \mathrm{NR}_{\mathrm{EP}}=\mathrm{NR}_{\mathrm{MP}}-\text { Subsidy }
$$

Thus, subsidy component has internalized into the model, by covering two aspects viz., fertilizer subsidy and irrigation subsidy. Fertilizer subsidy consisted subsidy on nitrogen $(\mathrm{N})$ and combination of Phosphorous (P) and Potassium (K). The total irrigation subsidy included canal, electricity and diesel subsidy and has been distributed over selected crops based on area under irrigation of each crop. Crop wise irrigation subsidy has two components: Ground water subsidy and Surface water subsidy. Ground water subsidy was estimated by initially calculating the crop-wise ground water use, i.e.

Groundwater use (cubic metre) $=$ Irrigation hours $(\mathrm{hrs} / \mathrm{ha}) \times$ Groundwater draft $(\mathrm{cum} / \mathrm{hr})$

The irrigation hours (hrs/ha) for each crop were taken from plot-wise CCS data. CCS does not collect information of ground water draft. Therefore, the groundwater draft was estimated using the following formula:

Ground water draft $(\mathrm{lit} / \mathrm{sec})=$

$$
\frac{\mathrm{HP} \times 75 \times \text { Pump Efficiency }}{\text { Total Head }(\mathrm{m})}
$$

The information on horse power (HP) of the pumps owned by the farmers was available in CCS data set. For the households purchasing groundwater, average HP of the pumps (estimated separately for electric and diesel) in respective tehsil can be taken as proxy. Pump efficiency was assumed to be 40 per cent. The total head was obtained as per below equation:

Total head $=$ Water level $(\mathrm{mbgl})+$ Draw down $(\mathrm{m})$ + Friction loss (10\% of water level + Draw down)

\section{Net Returns based on Natural Resource Valuation $\left(\mathrm{NR}_{\mathrm{NRV}}\right)$}

Net return based on Natural Resource Valuation (NRV) technique has taken care of nitrogen fixation by legume crops and Green House Gas (GHG) emission from crop production. As such $\mathrm{NR}_{\mathrm{NRV}}$ was computed by adding value of nitrogen fixation by legume crops at economic price of nitrogen (Value of $\mathrm{N}$ ) and deducting the imputed value of increase in GHG emission cost to the atmosphere.

$$
\text { i.e. } \mathrm{NR}_{\mathrm{NRV}}=\mathrm{NR}_{\mathrm{EP}}+(\text { Value of } \mathrm{N}-\text { cost of } \mathrm{GHG})
$$

Thus, legumes are environment-friendly crops and are different from other food plants because of the property of synthesizing atmospheric nitrogen into plant nutrients. As such, the economic valuation has been done by taking into account the positive externality of legume crops by biological nitrogen fixation and the negative externality of GHG emissions.

\section{RESULTS AND DISCUSSION}

\section{Changes in Cropping Pattern}

Table 1 indicated that Rajasthan state is basically a foodgrain production state as it occupies more than 50 per cent share of gross cropped area under foodgrains since 1991-95 to 2011-14. There was a sharp decline of 5.46 per cent in the cereals from 43.12 per cent in the year 1991-95 to 37.66 per cent in the year 2011-14 because of decrease in area under bajra by about 6.0 per cent from 24.41 per cent in the year 1991-95 to 18.77 per cent in the year 201114 followed by sorghum $(1.28 \%)$, maize $(0.88 \%)$ and paddy $(0.04 \%)$. An increase in area under total pulses was about 2.0 per cent from 14.81 per cent in the year 1991-95 to 16.52 per cent in the year 201114 due to an increase in area under greengram by 3.50 per cent. The share of total oilseeds was 17.30 per cent in the year 1991-95 which has increase to 19.43 per cent in the year 1996-2000, thereafter, it decreased and reached to 17.72 per cent in the year 2006-10. Further, it was increased to 20.15 per cent in the year 2011-14. The share of total spice has shown an increase about 1.59 per cent from 1.38 per cent in the year 1991-95 to 2.97 per cent in the year 201114 due to major increase in area under cumin from 0.70 per cent in the year 1991-95 to 1.77 per cent 
in the year 2011-14 followed by coriander (0.25\%). The crops like garlic, onion, potato, ajwain, isabgol, cotton and clusterbean has shown an increase in share of area during the study period.

Table 1: Changes in Cropping Pattern during 1990-91 to 2011-14 in Rajasthan state (per cent of GCA)

\begin{tabular}{|c|c|c|c|c|c|}
\hline Crops & 1991-95 & $\begin{array}{c}1996- \\
2000\end{array}$ & 2001-05 & 2006-10 & 2011-14 \\
\hline Bajra & 24.41 & 21.10 & 24.38 & 23.03 & 18.77 \\
\hline Maize & 3.33 & 3.08 & 3.56 & 3.03 & 2.45 \\
\hline Sorghum & 3.81 & 2.77 & 3.26 & 2.89 & 2.53 \\
\hline Paddy & 0.57 & 0.79 & 0.64 & 0.57 & 0.53 \\
\hline Wheat & 9.83 & 11.79 & 10.68 & 8.28 & 12.17 \\
\hline Barley & 1.18 & 1.01 & 0.99 & 0.86 & 1.22 \\
\hline Total Cereals & 43.12 & 40.55 & 43.50 & 38.66 & 37.66 \\
\hline Pegionpea & 0.13 & 0.15 & 0.11 & 0.09 & 0.07 \\
\hline Greengram & 1.60 & 2.51 & 3.40 & 4.07 & 4.11 \\
\hline Blackgram & 0.62 & 0.72 & 0.95 & 0.58 & 0.79 \\
\hline Mothbean & 5.16 & 5.02 & 5.86 & 5.57 & 4.68 \\
\hline Pea & 0.03 & 0.06 & 0.14 & 0.01 & 0.02 \\
\hline Gram & 6.83 & 8.85 & 4.40 & 3.85 & 6.36 \\
\hline Lentil & 0.06 & 0.17 & 0.10 & 0.04 & 0.14 \\
\hline Cowpea & 0.37 & 0.51 & 0.62 & 0.55 & 0.35 \\
\hline Total Pulses & 14.81 & 17.98 & 15.59 & 14.75 & 16.52 \\
\hline \multicolumn{6}{|l|}{ Total } \\
\hline Sesamum & 2.73 & 1.42 & 1.55 & 1.38 & 1.83 \\
\hline Groundnut & 1.30 & 1.35 & 1.23 & 1.41 & 1.62 \\
\hline Soybean & 1.22 & 2.48 & 3.02 & 3.45 & 3.86 \\
\hline Castorseed & 0.10 & 0.22 & 0.38 & 0.53 & 0.83 \\
\hline \multicolumn{6}{|l|}{ Rapeseed \& } \\
\hline Mustard & 11.18 & 12.51 & 10.10 & 10.56 & 10.38 \\
\hline Taramira & 0.58 & 1.36 & 0.95 & 0.38 & 1.65 \\
\hline Linseed & 0.18 & 0.07 & 0.02 & 0.01 & 0.01 \\
\hline Sunflower & 0.02 & 0.01 & 0.00 & 0.00 & 0.00 \\
\hline Total Oilseeds & 17.30 & 19.43 & 17.26 & 17.72 & 20.15 \\
\hline Coriander & 0.55 & 0.82 & 0.83 & 0.68 & 0.80 \\
\hline Cumin & 0.70 & 0.75 & 1.34 & 0.60 & 1.77 \\
\hline Fenugreek & 0.12 & 0.16 & 0.26 & 0.17 & 0.28 \\
\hline Fennel & 0.01 & 0.02 & 0.03 & 0.03 & 0.12 \\
\hline Total Spices & 1.38 & 1.76 & 2.47 & 1.48 & 2.97 \\
\hline Garlic & 0.03 & 0.06 & 0.09 & 0.07 & 0.18 \\
\hline Onion & 0.07 & 0.11 & 0.16 & 0.15 & 0.23 \\
\hline Chillies & 0.22 & 0.20 & 0.09 & 0.03 & 0.04 \\
\hline Potato & 0.01 & 0.01 & 0.02 & 0.03 & 0.04 \\
\hline Ajwain & 0.06 & 0.08 & 0.06 & 0.05 & 0.07 \\
\hline Isabgol & 0.00 & 0.34 & 0.52 & 0.57 & 0.81 \\
\hline Tobacco & 0.03 & 0.03 & 0.05 & 0.01 & 0.00 \\
\hline
\end{tabular}

\begin{tabular}{cccccc} 
Sugarcane & 0.12 & 0.12 & 0.05 & 0.03 & 0.02 \\
Cotton & 1.44 & 3.03 & 2.28 & 1.43 & 1.81 \\
Clusterbean & 7.44 & 9.52 & 10.69 & 12.79 & 15.60 \\
Other Crops & 11.93 & 6.82 & 7.22 & 12.25 & 3.90 \\
& 19455 & 20676 & 19195 & 21992 & 25145 \\
GCA ('000 ha) & $(100.00)$ & $(100.00)$ & $(100.00)$ & $(100.00)$ & $(100.00)$ \\
Cropping & & & & & \\
Intensity (\%) & 127 & 134 & 130 & 138 & 150 \\
Crop & & & & & \\
$\begin{array}{c}\text { Diversification } \\
\text { Index (S.I.D.) }\end{array}$ & 0.87 & 0.87 & 0.87 & 0.86 & 0.88 \\
\hline
\end{tabular}

Source: Various Issues of Statistical Abstract of Rajasthan, Agricultural Statistics of Rajasthan, Government of Rajasthan.

The clusterbean contributed remarkable share in gross cropped area and has shown significant increase about 8.0 per cent share of area from 7.44 per cent in the year 1991-95 to 15.60 per cent in the year 2011-14 due to its commercial use as guargum etc. whereas chillies, tobacco, sugarcane has shown slight decrease in area during the study period. The other crops like sugarcane, mehandi, jute, etc. also contributed the remarkable share in gross cropped area during the year 1991-95, it was 11.93 per cent but decreased to 7.22 per cent in the year 2001-05.

Thereafter, it was significantly increased to 12.25 per cent during the year 2006-10 and further it was again significantly declined to 3.90 per cent in the year 2011-14. During the overall study period, the cropping intensity has increased by 23 per cent (127\% to $150 \%)$. It seems that because of increase in irrigation facilities and technological development efforts, the intensity of crop cultivation has increased in the state. The crop diversification index has slightly increased by 0.01 ( 0.87 to 0.88 ) but closer to one thus indicated that there was more diversification of crops from sowing of traditional crops like bajra, maize, paddy, sorghum, sesamum, groundnut, kharif pulses, wheat, barley, gram and rapeseed \& mustard towards the high value crops like castorseed, clusterbean, soybean, cotton, cumin, fennel, coriander, ajwain, isabgol, opium, vegetables, fruit orchards etc. Thus, it can be concluded that total pulses, total oilseeds, total spices, garlic, onion, potato, ajwain, isabgol, cotton and clusterbean has shown an increase in the percentage share of area during the study period while total cereals, total foodgrains, chillies, tobacco, sugarcane and other crops has shown a decrease in share of area from the period 1991-95 to 2011-14. 


\section{Comparative Cost and Returns based on Market Price (MP)}

The comparative returns at market price along with variable cost for various crops in Rajasthan during TE 2013-14 were analyzed and presented in Table 2. Among the kharif crops, cotton cultivation in Rajasthan state has shown the highest variable cost of cultivation i.e. ₹ 51787 per hectare followed by paddy ( $₹ 52870 /$ ha), groundnut ( $₹ 34568 /$ ha) and it was observed lower the cost of cultivation in sesamum (₹ 12234/ha) whereas among the rabi crops, the variable cost was highest in onion cultivation (₹ 71069/ha) followed by garlic (₹ 69808/ ha), berseem ( $₹ 54165 /$ ha) and it was found lowest in coriander (₹ 18278/ha). The crops like wheat, barley, bajra, maize, sorghum and rapeseed \& mustard requires the lower cost of cultivation.

Table 2: Comparative Cost and Returns of Various Crops based on Market Price in Rajasthan during TE 2013-14 (₹/ha)

\begin{tabular}{ccccc}
\hline $\begin{array}{c}\text { Sl. } \\
\text { No. }\end{array}$ & Crops & $\begin{array}{c}\text { Variable } \\
\text { Cost } \\
\text { (A1+FL) }\end{array}$ & $\begin{array}{c}\text { Gross } \\
\text { Return }\end{array}$ & $\begin{array}{c}\text { Net Return } \\
\text { at Market } \\
\text { Price }\end{array}$ \\
\hline A & Kharif Crops & & & \\
\hline 1 & Bajra & 19585 & 24403 & 4818 \\
2 & Sorghum & 16799 & 20611 & 3812 \\
3 & Maize & 25720 & 32901 & 7181 \\
4 & Paddy & 52870 & 74571 & 21700 \\
5 & Cowpea & 13276 & 15288 & 2012 \\
6 & Blackgram & 15225 & 18017 & 2793 \\
7 & Greengram & 21231 & 30076 & 8846 \\
8 & Mothbean & 14135 & 9379 & -4756 \\
9 & Lentil & 22549 & 40780 & 18231 \\
10 & Sesamum & 12234 & 21429 & 9195 \\
11 & Soybean & 17499 & 36576 & 19077 \\
12 & Groundnut & 34568 & 56124 & 21555 \\
13 & Castorseed & 25541 & 53344 & 27803 \\
14 & Cotton & 51787 & 93216 & 41430 \\
15 & Clusterbean & 18406 & 48111 & 29705 \\
\hline B & Rabi Crops & & & \\
\hline 1 & Wheat & 32285 & 70308 & 38022 \\
2 & Barley & 30904 & 58809 & 27904 \\
3 & Gram & 18763 & 38776 & 20014 \\
4 & Rapeseed \& & & & \\
5 & Mustard & 22585 & 53781 & 31195 \\
6 & Cumin & 23047 & 31984 & 8937 \\
7 & Coriander & 18278 & 46917 & 28639 \\
& Fenugreek & 23256 & 39272 & 16016 \\
\hline
\end{tabular}

\begin{tabular}{ccccc}
8 & Onion & 71069 & 90588 & 19519 \\
9 & Garlic & 69808 & 101066 & 31258 \\
10 & Chillies & 48559 & 106496 & 57936 \\
11 & Vegetable & 37714 & 105352 & 67638 \\
12 & Berseem & 54165 & 72794 & 18630 \\
\hline
\end{tabular}

Source: Plot Level Cost of Cultivation Data of Rajasthan (TE 2013-14).

The gross return among the kharif crops has shown highest by cotton growers with ₹ 93216 per hectare followed by paddy ( $₹ 74571 /$ ha), groundnut ( $₹$ $56124 /$ ha) and gross return lowest produced by mothbean (₹ 9379/ha) while among rabi crops, the gross return was highest in chillies production (₹ 106496/ha) followed by vegetables (₹ 105353/ha), garlic (₹ 101066/ha), onion (₹ 90588/ha), wheat (₹ 70308/ha) and it was found lowest by cumin production i.e. ₹ 31984 per hectare. The net return over variable cost was seen highest among kharif crops in cotton cultivation i.e. ₹ 41430 per hectare followed by clusterbean ( $₹ 29705 /$ ha), castorseed (₹ 27803/ha) and lowest return observed in cowpea production ( $₹$ 2012/ha). Whereas among rabi crops, the vegetable production has shown the highest net return over variable cost of ₹ 67638 per hectare followed by chillies ( $₹ 57936 /$ ha), wheat ( $₹ 38022$ / ha) and lowest was seen in cumin cultivation (₹ 8937/ha). Mothbean cultivation in Rajasthan has shown the negative net return over variable cost of (-₹ 4756/ha). Results from the table indicated that cotton-vegetable combination of cropping pattern in overall Rajasthan has shown the highest return at market price of ₹ 109068 per hectare followed by cotton-chillies (₹ 99366/ha) and cotton-wheat (₹ 79452/ha).

\section{Net returns based on economic price (EP)}

The net returns based on economic prices for various crops in Rajasthan during TE 2013-14 were analyzed by deducting the input subsidies like NPK, electricity and diesel subsidies and has been presented in Table 3. Among all the crops, paddy cultivation received the highest NPK subsidy of ₹ 5046 per hectare followed by wheat ( $₹ 3195 /$ ha), garlic ( $₹ 2841 /$ ha), coriander ( $₹ 2617 /$ ha) and cotton ( $₹$ 2594/ha) because of the intensive use of fertilizer component in producing of these crops and lowest subsidy received by cowpea ( $₹ 17 /$ ha). Electricity subsidy was highest use in onion cultivation 
(₹ 2678/ha) followed by wheat (₹ 2284/ha) and barley (₹ 1667/ha) and it was found lowest in sorghum (₹ 15/ha) whereas onion cultivation has also shown the highest use of diesel subsidy of ₹ 360 per hectare followed by vegetables ( $₹$ 307/ha), barley ( $₹ 290 /$ ha) and lowest was use in greengram cultivation of ₹ $1 /$ ha. However, in overall total subsidy, wheat crop has received the highest total subsidy of ₹ 5714 per hectare followed by paddy ( $₹ 5492 /$ ha), onion ( $₹$ 5012/ha), garlic ( $₹$ 4481/ha) because of the higher use of fertilizer, electricity and diesel component in the cultivation of these crops and lowest was used in mothbean ( $₹$ 50/ha). After deducting the total subsidies from the net return at market prices, the net return based on economic prices was found highest in cotton cultivation with ₹ 37587 per hectare followed by clusterbean ( $₹ 29329 /$ ha), castorseed (₹ 26288/ha) and it was seen lowest in cowpea (₹ 1939/ha) among the kharif crop while among the rabi crops, vegetables has shown the highest net return of ₹ 65111 per hectare followed by chillies (₹ 54307/ha), wheat (₹ 32308/ha) and lowest was found in cumin cultivation (₹ 7036/ha). Among all the crops, the net return based on economic prices has shown the negative performance in the mothbean cultivation (-₹ 4806/ha).

Table 3: Crop-wise Net Returns based on Economic Price in Rajasthan during TE 2013-14 (₹/ha)

\begin{tabular}{|c|c|c|c|c|c|c|}
\hline $\begin{array}{l}\dot{0} \\
\dot{z} \\
\dot{\omega}\end{array}$ & ơ & $\begin{array}{l}\frac{1}{z} \\
\frac{n}{z} \\
\frac{2}{n}\end{array}$ & 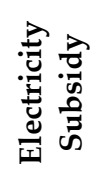 & 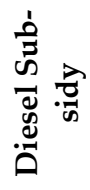 & 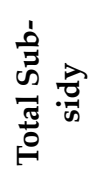 & 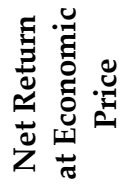 \\
\hline \multicolumn{7}{|c|}{ A Kharif Crops } \\
\hline 1 & Bajra & 792 & 150 & 19 & 961 & 3857 \\
\hline 2 & Sorghum & 727 & 15 & 99 & 841 & 2972 \\
\hline 3 & Maize & 2553 & 238 & 100 & 2891 & 4290 \\
\hline 4 & Paddy & 5046 & 445 & - & 5492 & 16209 \\
\hline 5 & Cowpea & 17 & 56 & - & 73 & 1939 \\
\hline 6 & Blackgram & 489 & 19 & - & 508 & 2284 \\
\hline 7 & Greengram & 462 & 65 & - & 527 & 8318 \\
\hline 8 & Mothbean & 21 & 30 & - & 50 & -4806 \\
\hline 9 & Lentil & 1781 & 160 & 98 & 2039 & 16192 \\
\hline 10 & Sesamum & 102 & 252 & 6 & 360 & 8835 \\
\hline 11 & Soybean & 597 & 75 & - & 672 & 18406 \\
\hline 12 & Groundnut & 1353 & 713 & 40 & 2106 & 19450 \\
\hline 13 & Castorseed & 562 & 934 & 20 & 1515 & 26288 \\
\hline 14 & Cotton & 2594 & 1037 & 211 & 3843 & 37587 \\
\hline 15 & Clusterbean & 214 & 151 & 10 & 376 & 29329 \\
\hline
\end{tabular}

\begin{tabular}{ccccccc}
\hline B & Rabi Crops & & & & & \\
\hline 1 & Wheat & 3195 & 2284 & 236 & 5714 & 32308 \\
2 & Barley & 1731 & 1667 & 290 & 3687 & 24217 \\
3 & Gram & 493 & 336 & 38 & 867 & 19147 \\
& Rapeseed \& & & & & & \\
4 & Mustard & 2072 & 1137 & 150 & 3360 & 27836 \\
5 & Cumin & 878 & 981 & 41 & 1900 & 7036 \\
6 & Coriander & 2617 & 820 & 4 & 3441 & 25198 \\
7 & Fenugreek & 963 & 983 & 83 & 2029 & 13987 \\
8 & Onion & 1973 & 2678 & 360 & 5012 & 14507 \\
9 & Garlic & 2841 & 1505 & 135 & 4481 & 26777 \\
10 & Chillies & 1954 & 1643 & 33 & 3630 & 54307 \\
11 & Vegetable & 1029 & 1192 & 307 & 2527 & 65111 \\
12 & Berseem & 2547 & 1439 & 64 & 4049 & 14580 \\
\hline
\end{tabular}

Source: Estimated using Plot Level Cost of Cultivation Data of Rajasthan (TE 2013-14).

Note: Subsidy @ ₹ 24.00/kg of N, ₹ 24.27/ kg of P and ₹ 23.19/kg of K for TE 2013-14, Diesel Subsidy @ ₹ 12.95 per litre, Electricity subsidy@ ₹ 3.03 per unit during TE 2013-14.

\section{Net returns based on natural resource valuation (NRV)}

The net returns based on natural resource valuation for various crops in Rajasthan during TE 2013-14 were analyzed by taking into account the positive impact of biological nitrogen fixation through the legume crops and negative impact of GHG emissions and has been presented in Table 4. The legume crop like groundnut has shown the highest economic contribution of ₹ 4560 per hectare through biological nitrogen fixation followed by soybean (₹ 3865/ha) and gram (₹ 3140/ha) while lentil fixed the nitrogen worth $₹ 1993$ per hectare.

Table 4: Crop-wise Net Returns based on Natural Resource Variation in Rajasthan during TE 2013-14 (₹/ha)

\begin{tabular}{ccccc}
\hline $\begin{array}{c}\text { Sl. } \\
\text { No. }\end{array}$ & Crops & $\begin{array}{c}\text { Value of } \\
\text { Nitrogen }\end{array}$ & $\begin{array}{c}\text { Value of } \\
\text { GHG }\end{array}$ & $\begin{array}{c}\text { Net } \\
\text { Return at } \\
\text { NRV }\end{array}$ \\
\hline A & Kharif & & & \\
\hline 1 & Bajra & 0 & 112 & 3745 \\
2 & Sorghum & 0 & 112 & 2860 \\
3 & Maize & 0 & 159 & 4131 \\
4 & Paddy & 0 & 1128 & 15081 \\
5 & Cowpea & 3110 & 97 & 4952 \\
6 & Blackgram & 2506 & 97 & 4693 \\
7 & Greengram & 2235 & 97 & 10456 \\
8 & Mothbean & 2235 & 97 & -2668
\end{tabular}




\begin{tabular}{ccccc}
9 & Lentil & 1993 & NA & 18185 \\
10 & Sesamum & 0 & 115 & 8720 \\
11 & Soybean & 3865 & 115 & 22156 \\
12 & Groundnut & 4560 & 115 & 23895 \\
13 & Castorseed & 0 & 115 & 26173 \\
14 & Cotton & 0 & NA & 37587 \\
15 & Clusterbean & 3533 & NA & 32862 \\
\hline B & Rabi & & & \\
\hline 1 & Wheat & 0 & 183 & 32125 \\
2 & Barley & 0 & 112 & 24105 \\
3 & Gram & 3140 & 97 & 22190 \\
4 & Rapeseed \& & & & \\
5 & Mustard & 0 & 115 & 27721 \\
6 & Cumin & 0 & NA & 7036 \\
7 & Coriander & 0 & NA & 25198 \\
8 & Fenugreek & 0 & NA & 13987 \\
9 & Onion & 0 & NA & 14507 \\
10 & Garlic & 0 & NA & 26777 \\
11 & Chillies & 0 & 235 & 54072 \\
12 & Vegetable & 0 & 235 & 64876 \\
\hline & Berseem & 0 & NA & 14580 \\
\hline
\end{tabular}

Source: Estimated by using Plot Level Cost of Cultivation data for TE 2013-14 and based on Peoples et al. (1995), IIPR (2003) and IARI (2014).

Paddy cultivation caused the highest negative externalities through the producing GHGs costing ₹ 1128 per hectare whereas the minimum GHG costs were incurred by cowpea, blackgram, greengram, mothbean and gram valued at ₹ 97 per hectare. Among the kharif crops, cotton cultivation has shown the highest net return based on natural resource valuation of ₹ 37587 per hectare followed by clusterbean ( $₹$ 32862/ha), castorseed ( $₹ 26173$ / ha) and it was found lowest in sorghum of ₹ 2860 per hectare whereas among the rabi crops, the vegetables has shown the highest net return of ₹ 64876 per hectare followed by chillies ( $₹ 54072 /$ ha), wheat (₹ 32125/ha) and it was observed lowest in cumin cultivation of ₹ 7036 per hectare. Mothbean has also shown the negative return (₹ 2668/ha) after adding the benefits of biological nitrogen fixation and deducting the GHG costs.

\section{Comparative Returns of Crops using Various Approaches of Valuation}

A comparative picture of net returns from various crops based on market prices, economic prices and natural resource valuation in Rajasthan during TE
2013-14 were analyzed and presented in Table 5.

Table 5: Net Returns from Different Crops using Various Approaches of Valuation in Rajasthan during TE 2013-14 (₹/ha)

\begin{tabular}{|c|c|c|c|c|}
\hline $\begin{array}{l}\text { Sl. } \\
\text { No. }\end{array}$ & Crops & $\begin{array}{c}\text { Net Return } \\
\text { at Market } \\
\text { Price }\end{array}$ & $\begin{array}{c}\text { Net Return } \\
\text { at Economic } \\
\text { Price }\end{array}$ & $\begin{array}{c}\text { Net Return } \\
\text { at Natural } \\
\text { Resource } \\
\text { Valuation }\end{array}$ \\
\hline \multicolumn{5}{|c|}{ A Kharif Crops } \\
\hline 1 & Bajra & 4818 & 3857 & 3745 \\
\hline 2 & Sorghum & 3812 & 2972 & 2860 \\
\hline 3 & Maize & 7181 & 4290 & 4131 \\
\hline 4 & Paddy & 21700 & 16209 & 15081 \\
\hline 5 & Cowpea & 2012 & 1939 & 4952 \\
\hline 6 & Blackgram & 2793 & 2284 & 4693 \\
\hline 7 & Greengram & 8846 & 8318 & 10456 \\
\hline 8 & Mothbean & -4756 & -4806 & -2668 \\
\hline 9 & Lentil & 18231 & 16192 & 18185 \\
\hline 10 & Sesamum & 9195 & 8835 & 8720 \\
\hline 11 & Soybean & 19077 & 18406 & 22156 \\
\hline 12 & Groundnut & 21555 & 19450 & 23895 \\
\hline 13 & Castorseed & 27803 & 26288 & 26173 \\
\hline 14 & Cotton & 41430 & 37587 & 37587 \\
\hline 15 & Clusterbean & 29705 & 29329 & 32862 \\
\hline \multicolumn{5}{|c|}{ B Rabi Crops } \\
\hline 1 & Wheat & 38022 & 32308 & 32125 \\
\hline 2 & Barley & 27904 & 24217 & 24105 \\
\hline 3 & Gram & 20014 & 19147 & 22190 \\
\hline 4 & $\begin{array}{c}\text { Rapeseed \& } \\
\text { Mustard }\end{array}$ & 31195 & 27836 & 27721 \\
\hline 5 & Cumin & 8937 & 7036 & 7036 \\
\hline 6 & Coriander & 28639 & 25198 & 25198 \\
\hline 7 & Fenugreek & 16016 & 13987 & 13987 \\
\hline 8 & Onion & 19519 & 14507 & 14507 \\
\hline 9 & Garlic & 31258 & 26777 & 26777 \\
\hline 10 & Chillies & 57936 & 54307 & 54072 \\
\hline 11 & Vegetable & 67638 & 65111 & 64876 \\
\hline 12 & Berseem & 18630 & 14580 & 14580 \\
\hline
\end{tabular}

Source: Plot Level Cost of Cultivation Data of Rajasthan (TE 2013-14).

After subtracting the input subsidies on fertilizers, electricity and diesel, there was a moderate to high decline in net return from the cultivation of various crops in the Rajasthan state. The impact of subsidies was so large in some cases. The withdrawal of input subsidies reduced the net return from maize to about 40 per cent followed by onion $(25.68 \%)$ and paddy $(25.30 \%)$. Due to high rate of profitability 
from the cultivation of vegetables, chillies, cotton, wheat, clusterbean and castorseed, the removal of input subsidies lowered the net income sharply. The profitability level of legume crops have increased by the biological nitrogen fixation while other crops have reduced the profitability level due to the GHG costing from various crops. After netting out the input subsidies and effect on environment and natural resources, the cotton-vegetables cropping pattern was found more stable and efficient because of the higher net return of ₹ 102463 per hectare with the next best alternate cropping patterns like clusterbean-chillies ( $₹ 86934 /$ ha), cotton-wheat (₹ 69712/ha), clusterbean-wheat (₹ 64987/ha).

\section{CONCLUSION}

Finally, it can be concluded that even after netting out the input subsidies and effect on environment and natural resources, the cotton-vegetables cropping pattern was found more stable and efficient because of the higher net return of ₹ 102463 per hectare with the next best alternate cropping patterns like clusterbean-chillies (₹ 86934/ha), cottonwheat (₹ 69712/ha), clusterbean-wheat (₹ 64987/ ha) etc. under the set of marketing infrastructure, minimum support prices, agricultural technological know-how, climatic conditions in the various zones, available irrigation facilities. Further, it can be say that the grower farmers may not move towards the diversification until incentivized by economically attractive alternate cropping patterns. The factors that are not captured by the market like subsidies is the direct cost to the society, factors affecting the natural resources and environment as nitrogen fixation and greenhouse gas costs, need to be considered and should be internalized through appropriate policies. Reckoning such costs and return alters the level of net income from various crops.

\section{REFERENCES}

Agriculture Statistics of Rajasthan, 2015-16. Directorate of Economics and Statistics, Government of Rajasthan. Available at: http://www. http://plan.rajasthan.gov.in

Agriculture Statistics at a Glance (Various Issues), Government of Rajasthan. Available at: http://www.krishi.rajasthan. gov.in.

Abdelaziz, H.H., Abdalla, A.A. and Abdellatif, M.A. 2010. Optimizing the Cropping Pattern in North Darfur State, Sudan: A Study of Dar Elslam District. Journal of Applied Sciences Research, 6(2): 156-164.
Ahmad, F.R., Basavaraja, H., Kunnal, L.B., Mahajanashetti, S.B. and Megeri. S.N. 2014. An Economic Analysis of Changes in Cropping Pattern in Karnataka. Karnataka Journal of Agricultural Science, 27(3): 312-315.

Burark, S.S., Sharma, L., Meena, G.L. and Jat, S. 2017. ICARSocial Science Network Project Report "Regional Crop Planning for Improving Resource Use Efficiency and Sustainability in Rajasthan". Department of Agricultural Economics and Management, RCA, MPUAT, Udaipur (Raj).

Dynamic Ground Water Resource of India. 2017. Central Ground Water Board, Ministry of Water Resources, River Development \& Ganga Rejuvenation Government of India Faridabad.

Deokate, T.B. and Bandgar, D.P. 2013. Changes in Landuse and Cropping Pattern in Maharashtra. Agricultural Economics Research Review, 26: 257.

Economic Review 2017-18. Directorate of Economics and Statistics, Government of Rajasthan. Available at: http:// www. http://plan.rajasthan.gov.in

GoI. 2013. Dynamic Ground Water Resources of India. Central Ground Water Board, Ministry of Water Resources, River Development \& Ganga Rejuvenation Government of India, New Delhi.

IARI. 2014. GHG Emission from Indian Agriculture: Trends, Mitigation and Policy Needs. Centre for Environment Science and Climate Resilient Agriculture, Indian Agriculture Research Institute, New Delhi, pp. 16.

IIPR. 2003. Pulses in New Perspective. In: Proceedings of the National Symposium on Crop Diversification and Natural Resource Management, Indian Institute of Pulses Research, Kanpur (U.P.), pp. 20-22.

Indian Fertilizer Scenario. 2013. Department of Fertilizers, Ministry of Chemicals and Fertilizers, Government of India, New Delhi.

Kaur, B., Sidhu, R.S. and Vatta, K. 2010. Optimal Crop Plans for Sustainable Water Use in Punjab. Agricultural Economic Research Review, 23: 273-284.

Pal, S. and Kar, S. 2012. Implications of the Methods of Agricultural Diversification in Reference with Malda district: Drawback and Rationale. International Journal of Food, Agriculture and Veterinary Sciences, 2(2): 97-105.

Rajasthan Electricity Regulatory Commission, Government of Rajasthan (Various Issues). Available at: http://www. rerc.rajasthan.gov.in.

Raju, S.S., Chanda, R., Srivastava, S.K., Kaur, A.P., Singh, J., Jain, R., Kingsly, I. and Kaur, P. 2015. Comparing Performance of Various Crops in Punjab Based on Market and Economic Prices and Natural Resource Accounting. Agricultural Economics Research Review, 28(Conference Number): 189-198.

Yadav, D.B., Gavali, A.V. and Kamble, B.H. 2017. ICAR-Social Science Network Project Report "Regional Crop Planning for Improving Resource Use Efficiency and Sustainability in Maharashtra". Department of Agricultural Economics, MPKV, Rahuri (M.S.). 